\title{
An Annotated List of the Fishes of the Western Basin of Lake Erie with Emphasis on the Bass Islands and Adjacent Tributaries
}

THOMAS P. SIMON', F.T. Stone Laboratory, The Ohio State University, Put-in-Bay, OH and School of Public and Environmental Affairs, Indiana University, Bloomington, IN; CHARLES BOUCHER, DAVID ALTFATER and DENNIS MISHNE, Ohio Environmental Protection Agency, Ecological Assessment Section, Groveport, OH; and BRIAN ZIMMERMAN, Museum of Biodiversity and Stream and River Ecology Lab, The Ohio State University, Columbus, OH.

ABSTRACT. Fish assemblage structure has changed dramatically in the Western Basin of Lake Erie since Trautman's revision of the Fishes of Ohio. Fish surveys near the Bass Islands and adjacent mainland tributaries documented fish faunal distributional patterns during the last three decades. Collections ( $n=1942$ sites) from 1980-2015 indicate 120 extant fish species and 19 extirpated species from the Bass Islands and nearby tributaries to the Western Basin. Extirpation of Polyodon spatula, Alosa sapidissima, Moxostoma lacerum, and Sander glacum occurred; however, Acipenser sapidissima and members of genus Oncorhynchus were introduced but unable to naturalize. Recent collection of rare species included A. fulvescens in Schoolhouse Bay near Middle Bass Island in May 2012; Umbra limi populations on Middle Bass Island and Kelley's Island; and Lepisosteus oculatus populations along the southeastern shoreline of North Bass Island are stable in Lake Erie despite cultural eutrophication. The current Western Basin fish assemblage includes 101 native, 12 nonindigenous, and seven alien fish species. Fourteen native species have been extirpated from the Western Basin of Lake Erie, while six nonindigenous species have not naturalized and have been extirpated. Introduced nonindigenous and alien species are responsible for increased species richness including Neogobius melanostomus, Proterorhinus semilunaris, Salmo trutta, Carassius auratus, Cyprinus carpio, Ctenopharyngodon idella and three records for Hypophthalmichthys nobilis since 1995. Hypophthalmichthys molitrix has never been collected but eDNA testing has indicated its presence. Neither H. nobilis or H. molitrix are considered established in Lake Erie, while Ctenopharyngodon idella may be reproducing within the basin. Brief comments on distribution, relative abundance, and status are provided for each species.

\section{INTRODUCTION}

Many factors have contributed to impacts on Great Lakes fishes, including cultural eutrophication, contamination, and theintroduction of nonindigenous and alien species that has contributed to the extinction of numerous native species (Mills et al. 1993; MacIsaac et al.2001; Ricciardi 2006). Invading species have bypassed the natural barriers of Niagara Falls with the opening of canals and waterways that enabled nonindigenous Atlantic slope species to enter Lake Erie (Daniels 2001). International shipping ports have provided beach heads for colonization of alien species and served as transoceanic dispersal routes of species into American ports from ballast water (Fuller et al. 1999; MacIssac 1999; Ricciardi 2001). In addition, the accidental escape of species from flooded aquaculture facilities has jeopardized the structure and function of

\footnotetext{
${ }^{1}$ Address correspondence to Thomas P. Simon, School of Public and Environmental Affairs, 1315 E. Tenth St., Indiana University, Bloomington, IN 47403. Email: tsimon@indiana. edu
}

the Great Lakes ecosystem with the potential dispersal of Asian carp through connections with the Mississippi River (Mills et al.1993; Fuller et al.1999).

At one time, Lake Erie possessed the highest species richness of fish of any Great Lake (Underhill 1986). The shallow, warm waters are conducive to a variety of colonizing species and provide a diversity of habitats which contribute to its high productivity. In Trautman's $(1957,1981)$ classic work on the Fishes of Ohio, he chronicled the demise and changing fish assemblage of Lake Erie in the vicinity of the Bass Islands during 1955-1980. Based on these accounts there is considerable evidence that the basin did not begin to change significantly until the middle of the 20th century (Trautman 1981). As a result of the alteration of coastal shoreline processes and the increased nutrient loading with intensive changing land use practices, (Trautman 1981; Underhill 1986), these basin-wide changes caused major modifications in the fish fauna. Trautman (1981) reported that by the late 1960s, several species of fish had been extirpated from the lake or from its tributaries. Van Meter and 
Trautman (1970) reported that more than 35 species of food fishes of significant commercial importance in Lake Erie had decreased to such an extent that they were of little or no economic value to commercial fisheries by 1970 . On the other hand, other species of lesser importance have increased in numbers because of the extensive changes including alien species such as the Black and Caspian Sea Gobiidae.

The sequence of events that transpired regarding the Lake Erie fish fauna during the last three decades required documentation to chronicle changes since Trautman's (1981) work. A significant amount of sampling has occurred since 1980 including surveys of the Portage (OEPA 1995a, 2010a), Maumee (OEPA 2010a), St. Joseph (OEPA 1994a, unpublished 2013 and 2015 data), St. Mary's (OEPA 1992a, unpublished 2015 data), Sandusky (OEPA 1991, 2000a, 2003a, 2010b, 2011), Blanchard (OEPA 2007a), East Fork Vermilion (OEPA 2008), Ottawa (OEPA 1998, 2000b, 2003c, 2007b, 2013), Tiffin (OEPA 1993, unpublished 2013 data), Toussaint (OEPA 2005a), and Vermilion (OEPA 2004) rivers. The Miami-Erie Canal (2012b), select tributaries of Lake Erie (OEPA 2004, 2010a), and estuaries such as Old Woman Creek (OEPA 2004) and Sandusky Bay (OEPA 2010b) were investigated. Tributary sampling included investigations of Swan Creek (OEPA 2009), Fish Creek (OEPA 1994b, 1995b, 1996, 2003b, 2005b), Loss Creek (OEPA 2012a), Riley and Little Riley Creek (OEPA 1992b), Armstrong Creek (2012b), and Chappel, Sugar, and Old Woman Creek (OEPA 2004, unpublished data 2015). Due to the ecological importance of Lake Erie, it is important to publish an updated annotated list of the lake's fishes. Historically, a total of 141 species of fishes are known (Dymond 1922; Fish 1932; Greeley 1929; Hubbs 1926; Hubbs and Brown 1929; Trautman 1935, 1957, 1981; MacKay 1963; Nelson and Gerking 1968; Scott 1967; Underhill 1986; Hubbs et al. 2004; Simon 2011), and where appropriate, comments on present and past distribution, abundance, and conservation status are provided in addition to present range for all previously known species in the Western Basin of Lake Erie and tributaries.

\section{STUDY AREA}

The Lake Erie Basin lies in the lacustrine plain of three physiographic sections including the Till Plains, Lake Plains, and Glaciated Plateau (Trautman 1981). The basin encompasses about $8936 \mathrm{~km}^{2}$ in Lake Erie, including the Maumee and Sandusky bays and adjacent tributaries draining from southeastern Michigan and northwestern Ohio (Figure 1). Tributary streams include the Bear Creek, Ottawa River, Maumee River, Crane Creek, Turtle Creek, Toussaint Creek, Portage River, Big Muddy Creek, Sandusky River, Cold Creek, Huron River, and Vermillion River. Drowned river mouth coastal wetlands associated with the coastal shoreline in the Western Basin are typically separated from Lake Erie along most of the Western Basin by a series of dikes and control structures, but some natural connections remain within the Sandusky and Maumee Bays. The current study includes all drowned river lacustrine and freshwater tributaries draining into Lake Erie that have been historically sampled from the mouth of the Detroit River in Michigan southeastward to the Vermillion River basin in Ohio.

\section{METHODS}

The annotated species information is based on 148 estuary, 1,509 tributary, and 62 Lake Erie coastal, island, and open water sites, comprising nearly 59,758 records. This study is based on collections of $1,654,782$ individuals that have been collected from 1980 2014. Sampling methods included a variety of gears appropriate for the habitat type under consideration; however, unpublished records from the Franz Theodore Stone Laboratory included information gathered by ichthyologists from other institutions during teaching and research activities at The Ohio State University. Collections described herein were made for many purposes and used a variety of gear types, ranging from seines to various forms of electrofishing equipment. Representative sampling included all habitats in the stream or lake reach being investigated relative to habitat occurrence using various sized seines or a Smith-Root Model $12-\mathrm{B}^{\circledast}$ battery powered backpack electrofishing unit, longline or tote barge wading electrofishing systems powered by a Baldore (formerly T\&J) 1750 watt, three-phase, bridge rectified, 250 volt pulsed DC electrofishing unit, Smith-Root DC generator mounted 5000 watt boat VVP electrofishing in drowned river mouth wetlands and Lake Erie coastal habitats, and deepwater otter trawls in open water, and beach seines along wadeable areas of Lake Erie. Ohio EPA follows consistent sampling methods (OEPA $1987 \mathrm{a}, \mathrm{b})$ that have been used consistently during the sampling period.

All large fish specimens were identified in the field and released, but voucher specimens were retained from each site. Each species' relative abundance was 
recorded in approximate proportion to abundance. Relative abundance information is defined by Smith (1965), Burr and Warren (1986), and Simon et al. (2002) and ranges in increasing order include: rare, sporadic, occasional, common, and abundant.
Conservation status refers to current status based on stable, imperiled, or invasive species designations as to population declining or expanding within range over the period 1980-2014. Records for Hypophthalmichthys molatrix, Oncorhynchusspecies, and Ctenopharyngodon

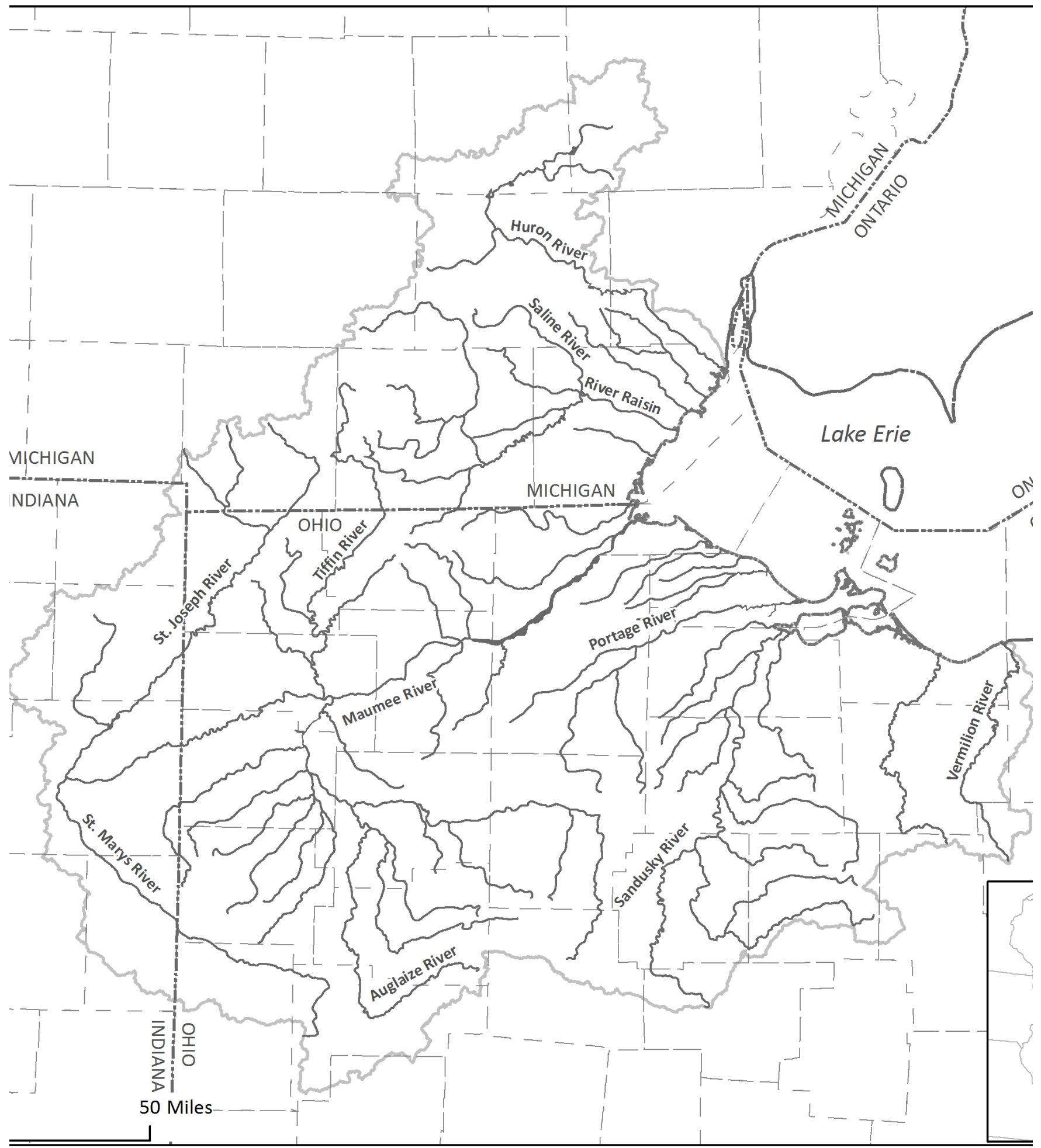

FIGURE 1. Study area showing the Bass Islands and tributaries associated with the Western Basin of Lake Erie (modified from USGS National Water Quality Assessment Program Lake Erie-Lake St. Clair base map). 
idella, do not have specific locations but are based on literature and unpublished information. Retained specimens were preserved in 10 percent formalin and transferred to 70 percent ethanol and identified using Trautman (1981), Hubbs et al. (2004), and Simon (2011).

In the species accounts, species are designated as native $(\mathrm{N})$, introduced nonindigenous species (I), and alien (E). Native species are defined as occurring within its original distributional range and would occur naturally in Lake Erie. Nonindigenous species would include species that enter a body of water or aquatic ecosystem outside of its historic or native range, i.e., basins outside of Lake Erie. An alien species is synonymous with "exotic" and is defined as a species living outside its native distributional range from either deliberate or accidental human introduction, i.e., areas external to North America (Courtney and Stauffer 1984).

Species are arranged in phylogenetic order by family and alphabetically by species within family. Scientific names are based on the Integrated Taxonomic Information System (ITIS), which is the most authoritative taxonomic information on organisms of North America and globally. It is updated regularly (ITIS 2015) and incorporates validated and recognized taxonomic information. Subspecific names were included only when it was believed that their inclusion was justified and when there was reasonable evidence (based on preserved material) that they were truly subspecies in Lake Erie. Species that lack factual records, i.e., without voucher specimens, were not included in this list.

Materials examined for the current study are not comprehensive, but represent the vouchered holdings of the F.T. Stone Laboratory on Gibraltar Island, The Ohio State University island campus. This compilation of information is based on the collective efforts of a number of ichthyologists including C. Levitt Smith (CLS), New York State Museum; Ted Cavender (TC), Museum of Biodiversity at The Ohio State University; and Timothy Berra (TB), The Ohio State University. The Ohio Environmental Protection Agency's extensive database was included for tributary, coastal shoreline of Lake Erie, and estuary records from biological assessments. All voucher specimens are cataloged into permanent research collections. Lake vouchers are curated at the Franz T. Stone Laboratory (OSUS) and stream and tributary specimens in the Museum of Biodiversity (OSUM). Extensive data collection records are maintained by Ohio Environmental Protection Agency, Ecological Assessment Section, Columbus. Indiana records are maintained by the Aquatic Research Center, Indiana Biological Survey (INBS), Bloomington, Indiana, and Michigan records by the University of Michigan Museum of Zoology (UMMZ).

\section{RESULTS AND DISCUSSION Drainage Diversity}

The present faunal list for the Western Basin of Lake Erie includes 139 species from the Bass Island and nearby Western Basin tributaries. Range extensions, invasive species colonization, and extirpations have influenced the previously known distribution information for the Western Basin since Trautman's (1981) monumental work on Ohio fishes. Collections ( $\mathrm{n}=1942$ sites) from $1980-2015$ indicate 120 extant fish species and 19 extirpated species from the Bass Islands and nearby tributaries to the Western Basin (Table 1, Appendix 1). Extirpation of Polyodonspatula, Alosa sapidissima, Moxostoma lacerum, and Sander glacum occurred; however, $A$. sapidissima and members of genus Oncorhynchus were introduced but unable to naturalize.

Recent collection of rare species included $A$. fulvescens in Schoolhouse Bay near Middle Bass Island in May 2012; Umbra limi populations on Middle Bass Island and Kelley's Island; and Lepisosteus oculatus populations along the southeastern shoreline of North Bass Island are stable in Lake Erie despite cultural eutrophication. The current Western Basin fish assemblage includes 101 native, 12 nonindigenous, and seven alien fish species. Fourteen native species have been extirpated from the Western Basin of Lake Erie, while six nonindigenous species have not naturalized and have been extirpated. Introduced nonindigenous and alien species are responsible for increased species richness including Neogobius melanostomus, Proterorhinus semilunaris, Salmo trutta, Carassius auratus, Cyprinus carpio, Ctenopharyngodon idella and three records for Hypophthalmichthys nobilis since 1995. Hypophthalmichthys molitrix has never been collected but eDNA testing has indicated its presence. Neither $H$. nobilis or $H$. molitrix are considered established in Lake Erie, while Ctenopharyngodon idella may be reproducing within the basin. Brief comments on distribution, relative abundance, and status are provided for each species. 
Table 1

Checklist of species from the Western Basin of Lake Erie including taxonomic nomenclature, common name and status. $\mathrm{N}=$ native, $\mathrm{E}=$ exotic, $\mathrm{I}=$ non-indigenous

Family Species

Petromyzontidae Ichthyomyzon unicuspis Hubbes and Trautman -- Silver Lamprey (N) Ichthyomyzon fossor Reighard and Cummins -- Northern Brook Lamprey (N) Lethenteron appendix (DeKay) -- American Brook Lamprey (N)

Petromyzon marinus Linnaeus -- Sea Lamprey (I)

Acipenseridae Acipenser fulvescens Rafinesque -- Lake Sturgeon (N)

Polyodontidae Polyodon spathula (Walbaum) -- Paddlefish (N)

Lepisosteidae Lepisosteus oculatus (Winchell) -- Spotted Gar (N) Lepisosteus osseus (Linnaeus) -- Longnose Gar (N)

Amiidae Amia calva Linnaeus -- Bowfin (N)

Hiodontidae Hiodon tergisus Lesueur -- Mooneye (N)

Clupeidae Alosa pseudoharengus (Wilson) -- Alewife (I) Alosa sapidissima (Wilson) -- American Shad (I) Dorosoma cepedianum (Lesueur) -- Gizzard Shad (N)

Salmonidae Oncorhynchus kisutch (Walbaum) -- Coho Salmon (I)

Oncorhynchus mykiss Richardson -- Rainbow Trout (I)

Oncorhynchus tshawytscha (Walbaum) -- Chinook Salmon (I)

Salmo salar Linnaeus -- Atlantic Salmon (I)

Salmo trutta Linnaeus -- Brown Trout (I/E)

Salvelinus fontinalis (Mitchill) -- Brook Trout (N)

Salvelinus namaycush (Walbaum) -- Lake Trout (N)

Coregonus artedi Lesueur -- Cisco or Lake Herring (N)

Coregonus clupeaformis (Mitchill) -- Lake Whitefish (N)

Osmeridae Osmerus m. mordax (Mitchill) -- Rainbow Smelt (I)

Umbridae Umbra limi (Kirtland) -- Central Mudminnow (N)

Esocidae Esox americanus vermiculatus Lesueur -- Grass Pickerel (N)

Esox lucius Linnaeus -- Northern Pike (N)

Esox masquinongy Mitchill -- Muskellunge (N)

Cyprinidae Campostoma a.anomalum (Rafinesque) -- Common Stoneroller (N)

Campostoma anomalum pullum (Agassiz) -- Central Stoneroller (N)

Carassius auratus (Linnaeus) -- Goldfish (E)

Chrosomus eos Cope -- Northern Redbelly Dace (N)

Chrosomus erythrogaster (Rafinesque) -- Southern Redbelly Dace (N) 
Table 1 (cont.)

Checklist of species from the Western Basin of Lake Erie including taxonomic nomenclature, common name and status. $\mathrm{N}=$ native, $\mathrm{E}=$ exotic, $\mathrm{I}=$ non-indigenous

\section{Family Species}

Clinostomus elongatus (Kirtland) -- Redside Dace (N)

Ctenopharyngodon idella (Valenciennes in Cuvier and Valenciennes, 1844) -- Grass Carp (E)

Cyprinella spilopterus (Cope) -- Spotfin Shiner (N)

Cyprinus carpio Linnaeus -- Common Carp (E)

Hybognathus hankinsoni Hubbs 1929 -- Brassy Minnow (I)

Hybopsis a. amblops (Rafinesque) -- Bigeye Chub (N)

Hypophthalmichthys molitrix (Valenciennes in Cuvier and Valenciennes) -- Silver Carp (E)

Hypophthalmichthys nobilis (Richardson) -- Bighead Carp (E)

Luxilus chrysocephalus (Rafinesque) -- Striped Shiner (N)

Luxilus cornutus frontalis (Mitchill) -- Northern Common Shiner (N)

Lythrurus umbratilis cyanocephalus (Copeland) -- Redfin Shiner (N)

Macrhybopsis storeriana (Kirtland) -- Silver Chub (N)

Nocomus biguttatus (Kirtland) -- Hornyhead Chub (N)

Nocomis micropogon (Cope) -- River Chub (N)

Notropis anogenus Forbes -- Pugnose Shiner (N)

Notropis ariommus (Cope) -- Popeye Shiner (N)

Notropis atherinoides Rafinesque -- Emerald Shiner (N)

Notropis boops Gilbert -- Bigeye Shiner (N)

Notropis buccatus Cope -- Silverjaw Minnow (N)

Notropis buchanani Meek -- Ghost Shiner (N)

Notropis heterodon (Cope) -- Blackchin Shiner (N)

Notropis heterolepis Eigenmann and Eigenmann -- Blacknose Shiner (N)

Notropis hudsonius (Clinton) -- Spottail Shiner (N)

Notropis photogenis (Cope) -- Silver Shiner (N)

Notropis rubellus (Agassiz) -- Rosyface Shiner (N)

Notropis stramineus (Cope) -- Sand Shiner (N)

Notropis v. volucellus (Cope) -- Mimic Shiner (N)

Notemigonus crysoleucas (Mitchill) -- Golden Shiner (N)

Opsopoeodus emiliae Hay -- Pugnose Minnow (N)

Phenacobius mirabilis (Girard) -- Suckermouth Minnow (I)

Pimephales p. promelas Rafinesque -- Fathead Minnow (N)

Pimephales notatus (Rafinesque) -- Bluntnose Minnow (N)

Pimephales vigilax (Baird and Girard) -- Bullhead Minnow (I)

Rhinichthys cataractae (Valenciennes) -- Longnose Dace (N)

Rhinichthys obtusus Agassiz -- Western Blacknose Dace (N)

Scardinius erythrophthalmus (Linnaeus) -- Rudd (E)

Semotilus atromaculatus (Mitchill) -- Creek Chub (N)

Catostomidae Carpiodes carpio (Rafinesque) -- River Carpsucker (I)

Carpiodes cyprinus (Lesueur) -- Quillback (N)

Catostomus catostomus (Forster) -- Longnose Sucker (N)

Catostomus commersonii (Lacepède) -- White Sucker (N)

Erimyzon claviformis (Girard) -- Creek Chubsucker (N) 
Table 1 (cont.)

Checklist of species from the Western Basin of Lake Erie including taxonomic nomenclature, common name and status. $\mathrm{N}=$ native, $\mathrm{E}=$ exotic, $\mathrm{I}=$ non-indigenous

\section{Family Species}

Ictaluridae Ameiurus catus (Linnaeus) -- White Catfish (I)

Ameiurus melas (Rafinesque) -- Black Bullhead (N)

Ameiurus natalis (Lesueur) -- Yellow Bullhead (N)

Ameriurus nebulosus (Lesueur) -- Brown Bullhead (N)

Ictalurus punctatus (Rafinesque) --Channel Catfish (N)

Noturus flavus Rafinesque -- Stonecat (N)

Noturus gyrinus (Mitchill) -- Tadpole Madtom (N)

Noturus miurus Jordan -- Brindled Madtom (N)

Noturus stigmosus Taylor -- Northern Madtom (N)

Pylodictis olivaris (Rafinesque) -- Flathead Catfish (I)

Anguillidae Anguilla rostrata (Lesueur) -- American Eel (N)

Fundulidae $\quad$ Fundulus diaphanus menona Jordan and Copeland -- Western Banded Killifish (N)

Fundulus notatus (Rafinesque) -- Blackstripe Topminnow (N)

Poeciliidae Gambusia affinis (Baird and Girard) -- Western Mosquitofish (I)

Gadidae Lota lota (Linnaeus) -- Burbot (N)

Gasterosteidae Culaea inconstans (Kirtland) -- Brook Stickleback (N)

Gasterosteus aculeatus Girard -- Threespine Stickleback (I)

Atherinopsidae Labidesthes sicculus (Cope) -- Brook Silverside (N)

Percopsidae Percopsis omiscomaycus (Walbaum) -- Trout-perch (N)

Aphredoderidae Aphredoderus sayanus (Gilliams) -- Pirate Perch (N)

Moronidae Morone americana (Gmelin) -- White Perch (I) 
Table 1 (cont.)

Checklist of species from the Western Basin of Lake Erie including taxonomic nomenclature, common name and status. $\mathrm{N}=$ native, $\mathrm{E}=$ exotic, $\mathrm{I}=$ non-indigenous

\section{Family} Species

Morone chrysops (Rafinesque) -- White Bass (N)

Centrarchidae Ambloplites rupestris (Rafinesque) -- Rock Bass (N)

Lepomis cyanellus Rafinesque -- Green Sunfish (N)

Lepomis gibbosus (Linnaeus) -- Pumpkinseed (N)

Lepomis gulosus (Cuvier) -- Warmouth (N)

Lepomis humilis (Girard) -- Orangespotted Sunfish (I)

Lepomis macrochirus Rafinesque -- Bluegill (N)

Lepomis microlophus (Gunther) -- Redear Sunfish (I)

Lepomis peltastes Cope -- Northern Longear Sunfish (N)

Micropterus dolomieu Lacepède -- Smallmouth Bass (N)

Micropterus salmoides Lacepède -- Largemouth Bass (N)

Pomoxis annularis Rafinesque -- White Crappie (N)

Pomoxis nigromaculatus (Lesueur) -- Black Crappie (N)

Percidae Sander canadensis (Griffith and Smith) -- Sauger (N)

Sander vitreus (Mitchill) -- Walleye $(\mathrm{N})$

Perca flavescens (Mitchill) -- Yellow Perch (N)

Ammocrypta pellucida (Putnam) -- Eastern Sand Darter (N)

Etheostoma blennioides pholidotum Rafinesque -- Prairie Darter $(\mathrm{N})$

Etheostoma caeruleum Storer -- Rainbow Darter (N)

Etheostoma exile (Girard) -- Iowa Darter (N)

Etheostoma flabellare Rafinesque -- Fantail Darter (N)

Etheostoma microperca Jordan and Gilbert -- Least Darter (N)

Etheostoma nigrum eulepis (Hubbs and Greene) -- Scaly Darter (N)

Etheostoma n. nigrum Rafinesque -- Johnny Darter (N)

Etheostoma spectabile (Agassiz) -- Orangethroat Darter (N)

Percina caprodes (Rafinesque) -- Logperch (N)

Percina copelandi (Jordan) -- Channel Darter (N)

Percina evides (Jordan and Copeland) -- Gilt Darter (N)

Percina maculata (Girard) -- Blackside Darter (N)

Percina sciera (Swain) -- Dusky Darter (I)

Percina shumardi (Girard) -- River Darter (N)

Sciaenidae Aplodinotus grunniens Rafinesque -- Freshwater Drum (N)

Cottidae Cottus bairdii Girard -- Mottled Sculpin (N)

Cottus ricei (Nelson) -- Spoonhead Sculpin (N)

Gobiidae Neogobius melanostomus (Pallus) -- Round Goby (E)

Proterorhinus semilunaris (Heckel) -- Tubenose Goby (E) 


\section{Historical Assemblage and Range Extensions}

Trautman (1981) chronicled the sequence of events that transpired regarding the Lake Erie fish fauna from 1801 to 1980 . He reported that a total of 122 species and seven additional subspecies were listed as occurring during the period from 1750 and 1950 . Trautman (1981) indicted that the species richness of Lake Erie and its connecting bays and harbors included 93 species and six additional subspecies. The greatest richness was attributed to the Maumee River that included 93 species and two subspecies.

Trautman (1981) reported that 2500 localities were collected from 1840 to 1950 . A significant amount of sampling has occurred since 1980 with nearly 1,942 sites sampled with more than 2,500 collections from those sites. Our inventories increased the cumulative list of species found in the Western Basin of Lake Erie from Ohio, Michigan, and Indiana by 21 species. Many of the added species are nonindigenous, alien, or rare species experiencing range resurgence. Introduced species such as Neogobius melanostomus and Proterorhinus semilunaris first appeared in the drainage after 1993, while Asian carps such as Hypopthalmichthys nobilis were found in 2000 and Ctenopharyngodon idella since 2009, have been reported from Sandusky Bay, Cedar Point, and elsewhere by eDNA (Great Lakes Fishery Commission-Lake Erie Committee 2015). Taxonomic changes and anthropogenic range extensions have accounted for increased species richness, especially with the stocking of salmon genera including Oncorhynchus and Salmo, Osmerus m. mordax, Pylodictis olivaris, and Ctenophyngodon idella. In addition, minnow, sunfish, and darter species have been elevated from subspecies to full species since Trautman (1981). Taxonomic recognition of Campostoma a. anomalum, C. a.pullum, Lepomis peltastes, Etheostoma blennioides pholidotum, and E. nigrum eulepis have been elevated from synonymy with former species complexes (Hubbs et al. 2004; Simon 2011). Five range extensions within the drainage were found based on a more comprehensive sampling effort. New localities for Notropis buchanani, Fundulus diaphanus menona, Aphredoderus sayanus, Ammocrypta pellucida, and Percina sciera have been recorded from the Western basin.

\section{ACKNOWLEDGMENTS}

The authors thank students, colleagues, and peers who assisted with obtaining the nearly 58,000 site records used for the current study. Special thanks to Roger Thoma, Chris Yoder, C. Lavett Smith,
Ted Cavender, and Tim Berra for depositing specimens in the F.T. Stone Laboratory collection and to Marc Kibbey for contributing data from the OSUM. The opinions expressed do not necessarily represent those of the State of Ohio Environmental Protection Agency. This study was supported by Friends of Stone Lab and The Ohio State University.

\section{LITERATURE CITED}

Bailey RM, Latta WC, Smith GR. 2004. An atlas of Michigan Fishes with keys and illustrations for their identification. University of Michigan, No. 192. Ann Arbor.

Burnham-Curtis MK. 1998. Mitochondrial DNA variation among populations of brook trout (Salvelinus fontinalis) in the Chagrin River Drainage, Ohio and upper Ohio River drainage, Pennsylvania. US Fish and Wildl Serv, Ohio Dept Nat Res, US Geol Surv-Biol Res Div, Columbus, OH. [accessed 2016 March 19]. file://C:/Users/Simon/ Downloads/660841_burnham_curtis_2001.pdf

Burr BM, Warren, Jr, ML. 1986. Adistributional atlas of Kentucky fishes. Frankfort, KY: Kentucky Nature Preserves Commission. Scientific Technical Series No. 4.

Chapman DC, Davis JJ, Jenkins JA, Kocovsky PM, Miner JG, Farver J, Jackson PR. 2013. First evidence of grass carp recruitment in the Great Lakes basin. J Great Lakes Res 39:547-554. http://dx.doi.org/10.1016/j.jglr.2013.09.019

Clem PD, Whitaker, Jr., JO. 1995. Distribution of the mosquitofish, Gambusia affinis (Baird and Girard), in Indiana, with comments on resource competition. Proc Ind Acad Sci 104:249-258.

Cook A, Kayle K. 2006. Charge 2: continue to assess the whitefish population age structure, growth, diet, seasonal distribution and other population parameters. In Report of the Lake Erie Coldwater Task Group. [accessed 2016 March 13\} http:// www.glfc.org/lakecom/lec/CWTG docs/annual reports/ CWTG report 2006.pdf

Courtney WR, Stauffer JR. 1984. Distribution, biology, and management of exotic fishes. Baltimore: The John Hopkins University Press.

Cudmore B, Mandrak NE, Dettmers J, Chapman DC, Kolar CS. 2011. Binational ecological risk assessment of bighead carps (Hypothalmichthys spp) for the Great Lakes Basin. [accessed 2016 March 13] http://www.dfo-mpo.gc.ca/Csassccs/publications/resdocs-docrech/2011/2011_114-eng.pdf

Daniels RA. 2001. Untested assumptions: the role of canals in the dispersal of sea lamprey, alewife, and other fishes in the eastern United States. Env Biol Fishes 60: 309-329.

Dowell SA. 2010. Morphological and genetic investigations of Pennsylvania populations of the channel shiner, Notrpis wickliff. [master's thesis]. [Pittsburgh]: Duquesne University.

Dymond JR. 1922. A provisional list of the fishes of Lake Erie. University of Toronto Studies, Publications of the Ontario Fisheries Research Laboratory 4:57-73. [accessed 2016 March 19] http://www.harkness.ca/PDFs/OFRL\%20Publications/ Journal4.pdf

Fish MP. 1932. Contributions of the early life histories of sixtytwo species of fish from Lake Erie and its tributary waters. Bull US Bur Fish 47: 293-398. [accessed 2016 March 19]. http://docs.lib.noaa.gov/rescue/Fish_Commission_Bulletins/ BFC1931-1933-v47.PDF 
Fuller PL, Nico LG, Williams JD. 1999. Nonindigenous fishes introduced into inland waters of the United States. Bethesda, MD: American Fisheries Society. Special Publication 27.

Gilbert CR. 1969. Systematics and distribution of the American cyprinid fishes Notropis ariommus and Notropis telescopus. Copeia 1969(3): 474-492. http://dx.doi. org/10.2307/1441927

Grant, K.A., M.J. Shadle, and G. Andraso. 2012. First report of tubenose goby (Proterorhinus semilunaris) in the eastern basin of Lake Erie. J Great Lakes Res 38:821-824. http://dx.doi. org/10.1016/j.jglr.2012.09.019

Great Lakes Fishery Commission. 2015. Bighead and Silver Carp in the Lake Erie System: 2014 update. [accessed 2016 March 13] http://www.glfc.org/lakecom/lec/LEC docs/other docs/ LEC Asian Carp Fact Sheet 2015.pdf

Greeley JR. 1929. Fishes of the Erie-Niagara watershed [with annotated list] In: A biological survey of the Erie-Niagara system. Suppl. 18thAnn Rept.[accessed2016March 13] https:// archive.org/stream/biologicalsurvey00newy\#page/150/ mode/2up/search/greeley.

Haponski AE. 2007. Molecular, morphological, and biogeographic resolution of cryptic taxa in the greenside darter Etheostoma blennioides complex. [master's thesis]. [Toledo]: University of Toledo. [accessed 2016 March 19]. http://utdr.utoledo. edu/theses-dissertations/1280/

Hubbs CL. 1926. A check list of the fishes of the Great Lakes and tributary waters, with nomenclatorial notes and analytical keys. [accessed 2016 March 13]. https://deepblue.lib.umich.edu/ bitstream/handle/2027.42/56260/MP015.pdf?sequence $=1$

Hubbs CL, Brown DES. 1929. Materials for a distributional study of Ontario fishes. Toronto: University of Toronto Press.

Hubbs CL, Greene CW. 1935. Two new subspecies of fishes from Wisconsin. Trans Wisc Acad Sci Arts and Letters 29: 89-101.

Hubbs CL, Lagler KF, Smith GR. 2004. Fishes of the Great Lakes Region, revised edition. Ann Arbor: University of Michigan Press.

Integrated Taxonomic Information System. 2015. [accessed 2015 June 15]. http://www.itis.gov.

Jude DJ, Reider RH, Smith GR. 1992. Establishment of Gobiidae in the Great Lakes basin. Can J Fish Aquat Sci 49: 416-421. http://dx.doi.org/10.1139/f92-047

Kenyon R., Murray C. 2001. A review of the Lake Erie and Presque Isle Bay yellow perch sport angling fisheries, 1997-2001. Fairview, PA: Pennsylvania Fish and Boat Comm. [accessed 2016 March 13]. http://fishandboat.com/images/fisheries/ afm/2001/afm1 leru 01.htm.

Kocovsky PM, Tallman JA, Jude DJ, Murphy DM, Brown JE, Stepien CA. 2011. Expansion of tubenose gobies, Proterorhinus semilunaris into western Lake Erie and potential effects on native species. Biol Invasions 13: 2775-2784. http://dx.doi. org/10.1007/s10530-011-9962-5

Kuehn RA, Barbour RW. 1983. American darters. Lexington: University of Kentucky Press.

Lagler KF, Bailey RM. 1947. The genetic fixivity of differential characters in subspecies of the percid fish, Boleosoma nigrum. Copeia 1947:50-59.

Lee SL, Gilbert CR, Hocutt CH, Jenkins RE, McAllister DE, and Stauffer JR. 1980. Atlas of North American freshwater fishes. Raleigh: North Carolina State Museum of Natural History.

Locke B, Belore M, Cook A, Einhouse D, Kenyon R, Knight R, Newman K, Ryan P, Wright E. 2005. Lake Erie Walleye Management Plan. [accessed 2016 March 13]. http://www. glfc.org/lakecom/lec/WTG_docs/other_reports_and_docs/ wmp20051207.pdf. .

MacKay HH. 1963. Fishes of Ontario. Toronto: Ontario Dept. of Lands and Forests.

MacIsaac HJ, Grigorovich IA, Ricciardi A. 2001. Reassessment of species invasions concepts: the Great Lakes basin as a model. Biol Invasions 3: 405-416.

MacIsaac HJ. 1999. Biological invasions in Lake Erie: past present and future. In: Munawar M, . Edsall T, Munawar IF, editors. State of Lake Erie: Past, Present and Future. Netherlands:Backhuys. P 305-322.

Markham J. 2006a. Charge 1: Coordinate annual standardized lake trout assessments among all eastern basin agencies and report upon the status of lake trout rehabilitation. In Report of the Lake Erie Coldwater Task Group. [accessed 2016 March 13$\}$ http://www.glfc.org/lakecom/lec/CWTG docs/ annual reports/CWTG report 2006.pdf

Markham J. 2006b. Charge 7: Monitor the current status of Lake Herring. Review ecology and history of this species and assess potential for recovery In Report of the Lake Erie Coldwater Task Group. [accessed 2016 March 13]. http:// www.glfc.org/lakecom/lec/CWTG docs/annual reports/ CWTG report 2006.pdf

Markham J, Kayle K. 2006. Charge 8: Improve description of diet for top coldwater predators. Charge 8, pp. 1-6. In Report of the Lake Erie Coldwater Task Group. [accessed 2016 March 13]. http://www.glfc.org/lakecom/lec/CWTG docs/ annual reports/CWTG report 2006.pdf

McAllister DE. 1984. Osmeridae. In Whitehead PJP, Bauchot ML,Hureau JC, Nielsen J, Tortonese E, editors. Fishes of the north-eastern Atlantic and the Mediterranean. Paris: UNESCO.

Mills EL, Leach JH, Carlton JT, Secor CL. 1993. Exotic species in the Great Lakes: A history of biotic crises and anthropogenic introductions. J Great Lakes Res 19: 1-54. http://dx.doi. org/10.1016/S0380-1330(93)71197-1

Miller RV. 1968. A systematic study of the greenside darter, Etheostoma blennioides Rafinesque (Pisces; Percidae). Copeia 1969 (1): 1-40.

Miltner RJ. 2015. Measuring the contribution of agricultural conservation practices to observed trends and recent condition in water quality indicators in Ohio, USA. J Environ Qual 44 (6): 1821-1831.http://dx.doi.org/10.2134/jeq2014.12.0550

Nelson JS, Gerking SD. 1968. Annotated key to the fishes of Indiana. Bloominton: Indiana University. [accessed 2016 March 13]. http://www.nativefishlab.net/library/ textpdf/19632.pdf

[Ohio DNR] Ohio Department of Natural Resources. 2014. Ohio's Lake Erie Fisheries 2013. Ann Status Rept. Federal Aid Sport Fish Restor Proj F-69-P. Ohio Depart Nat Res, Div. Wild, Lake Erie Fish Unit, Fairport and Sandusky. 123 p.

[OEPA] Ohio Environmental Protection Agency. 1987a. Biological criteria for the protection of aquatic life: volume II. Users Manual for Biological Field Assessment of Ohio Surface Waters. Columbus, OH: Ohio EPA. [accessed 2016 March 13]. http://www.epa.state.oh.us/Portals/35/ documents/Vol2.pdf.

[OEPA] Ohio Environmental Protection Agency. 1987b. Biological criteria for the protection of aquatic life: volume III. Standardized biological field sampling and laboratory methods for assessing fish and macroinvertebrate communities. Columbus, OH: Ohio EPA. [accessed 2016 March 19]. http:// epa.ohio.gov/portals/35/documents/BioCrit15_Vol3.pdf

[OEPA] Ohio Environmental Protection Agency. 1991. Biological and water quality study of the Sandusky River and selected 
tributaries: Crawford, Wyandot, and Seneca counties, Ohio. Columbus: Ohio EPA, Technical Report 05-001. [accessed 2016 March 19]. http://epa.ohio.gov/portals/35/documents/ Sandusky1991.pdf

[OEPA] Ohio Environmental Protection Agency. 1992a. Biological and water quality survey of the St. Mary's River: Auglaize and Mercer counties, Ohio. Columbus: Ohio EPA, Report EAS/1992-11-10. [accessed 2016 March 19]. http:// www.epa.ohio.gov/portals/35/documents/stmary91.pdf

[OEPA] Ohio Environmental Protection Agency. 1992b. Biological and water quality study of Riley Creek and Little Riley Creek: Hancock, Allen, and Putnam counties, Ohio. Columbus: Ohio EPA, Technical Report EAS/1992-8-6. [accessed 2016 March 19]. http://www.epa.ohio.gov/ portals/35/documents/RileyCreek1992.pdf

[OEPA] Ohio Environmental Protection Agency. 1993. Biological and water quality study of the Tiffin River: Fulton, Williams, and Defiance counties, Ohio. Columbus: Ohio EPA, Technical Report EAS/1993-12-5. [accessed 2016 March 19]. http:// www.epa.ohio.gov/portals/35/documents/Tiffin1993.pdf

[OEPA] Ohio Environmental Protection Agency. 1994 a. Biological and water quality Survey of the St. Joseph River and Selected Tributaries: Williams and Defiance counties, Ohio. Columbus: Ohio EPA, Report DSW/EAS 199312-7. [accessed 2016 March 19]. http://www.epa.ohio.gov/ portals/35/documents/stjoe.pdf

[OEPA] Ohio Environmental Protection Agency. 1994b. Summary of fish community assessment results for Fish Creek 1991-1993: Steuben and Dekalb counties, Indiana and Williams county, Ohio. Columbus: Ohio EPA, Technical Report DSW/EAS 1994-6-10. [accessed 2016 March 19]. http://www.epa.ohio.gov/portals/35/documents/fish9193. pdf

[OEPA] Ohio Environmental Protection Agency. 1995a. Biological and Water Quality Study of the Portage River and Selected Tributaries: Hancock, Ottawa, Sandusky, Seneca and Wood counties. Columbus: Ohio EPA, Technical Report MAS/1995-12-7. [accessed 2016 March 19]. http://www. epa.ohio.gov/portals/35/documents/portg94.pdf

[OEPA] Ohio Environmental Protection Agency. 1995b. Fish and macroinvertebrate study of Fish Creek 1994. Columbus: Ohio EPA, Technical Report MAS/1995-2-1. [accessed 2016 March 19].http://www.epa.ohio.gov/portals/35/documents/ fishcr94.pdf

OEPA] Ohio Environmental Protection Agency. 1996. Addendum to fish and macroinvertebrate study of Fish Creek 1994: Steuben and Dekalb counties, Indiana, and Williams county, Ohio. Columbus: Ohio EPA, Technical Report MAS/1996-9-5. [accessed 2016 March 19]. http://www. epa.ohio.gov/portals/35/documents/fishcr95.pdf

[OEPA] Ohio Environmental Protection Agency. 1998. Biological and water quality study of the Ottawa River basin (1996): Allen and Putnam counties, Ohio. Columbus: Ohio EPA, Technical Report MAS/1997-12-6. [accessed 2016 March 19]. http:// www.epa.ohio.gov/portals/35/documents/ottlim96.pdf

[OEPA] Ohio Environmental Protection Agency. 1999. Fish tissue study of the Ottawa River, Toledo, Ohio: Lucas County, 1999. Columbus: Ohio EPA, Technical Report MAS/2000-2-1. [accessed 2016 March 19]. http://www. epa.ohio.gov/portals/35/documents/Ottawa99.pdf

[OEPA] Ohio Environmental Protection Agency. 2000a.
Biological and water quality study of Sycamore Creek and the Sandusky River 1999. Columbus: Ohio EPA, Technical Report EAS/2000-6-3. [accessed 2016 March 19]. http:// www.epa.ohio.gov/portals/35/documents/kirby99.pdf.

[OEPA] Ohio Environmental Protection Agency. 2000b. Fish tissue study of the Ottawa River 1999. Columbus: Ohio EPA, Technical Report MAS/2000-2-1. [accessed 2016 March 19].http://www.epa.ohio.gov/portals/35/documents/ Ottawa99.pdf

[OEPA] Ohio Environmental Protection Agency. 2003a. Biological and water quality study of the Sandusky River and selected tributaries 2001: Seneca, Wyandot, and Crawford Counties, Ohio. Columbus: Ohio EPA, Technical Report EAS/2003-4-6. [accessed 2016 March 19]. http://www. epa.ohio.gov/portals/35/documents/2001SanduskyTSD.pdf

[OEPA] Ohio Environmental Protection Agency. 2003b. Fish and macroinvertebrate study of Fish Creek 1997: Steuben and Dekalb counties, Indiana and Williams county, Ohio. Columbus: Ohio EPA, Technical Report EAS/2003-2-4. [accessed 2016 March 2016]. http://www.epa.ohio.gov/ portals/35/documents/FishCr1997.pdf

[OEPA] Ohio Environmental Protection Agency. 2003c. Biological, fish tissue, and sediment study of the Ottawa River, Dura Avenue Landfill 2002: Lucas county, Ohio. Columbus: Ohio EPA, Technical Report EAS/2003-1-2. [accessed 2016 March 19]. http://www.epa.ohio.gov/portals/35/documents/ OttawaRDura2002.pdf

[OEPA] Ohio Environmental Protection Agency. 2004. Biological and water quality study of the Vermilion River, Old Woman Creek, Chappel Creek, Sugar Creek, and select Lake Erie tributaries, 2002: Ashland, Huron, Erie, Richland, and Lorain counties, Ohio. Columbus: Ohio EPA, Technical Report EAS/2004-10-22. [accessed 2016 March 19]. http://www. epa.ohio.gov/portals/35/documents/VermilionTSD2004.pdf

[OEPA] Ohio Environmental Protection Agency. 2005a. Biological and water quality study of the Toussaint River, Toussaint Creek, Packer Creek, Rusha Creek, Martin Ditch, and Gust Ditch, 2003: Ottawa, Sandusky, and Wood counties. Columbus: Ohio EPA, Report EAS/2005-4-4. [accessed 2016 March 19]. http://www.epa.ohio.gov/portals/35/ documents/Toussaint2005TSD_1.pdf

[OEPA] Ohio Environmental Protection Agency. 2005b. Biological and water quality study of Fish Creek 2002: Steuben and Dekalb counties, Indiana, and Williams county, Ohio. Columbus: Ohio EPA, Technical Report MAS/20052-2. [accessed 2016 March 19]. http://www.epa.ohio.gov/ portals/35/documents/FishCr2002TSDfinal.pdf

[OEPA] Ohio Environmental Protection Agency. 2006a. Biological and water quality study of the East Fork Vermilion River green circle growers project 2005: Lorain and Erie counties, Ohio. Columbus: Ohio EPA, Technical Report DSW/EAS 2006-3-2. [accessed 2016 March 19]. http://www. epa.ohio.gov/portals/35/documents/EFVermilionTSD2006. pdf

[OEPA] Ohio Environmental Protection Agency. 2007a. Biological and water quality study of the Blanchard River and selected tributaries 2005: Putnam, Hancock, Seneca, Allen, Wyandot, and Hardin counties, OH. Columbus: Ohio EPA, Technical Report EAS/2007-6-2[accessed 2016 March 19].http://www.epa.ohio.gov/portals/35/documents/ BlanchardRiverTSD2005.pdf

[OEPA] Ohio Environmental Protection Agency. 2007b. Biological and water quality study of the Ottawa River, 
Lower Nine Miles, 2007: Lucas County, Ohio. Columbus: Ohio EPA, Report EAS/2007-12-12. [accessed 2016 March 19]. http://www.epa.ohio.gov/portals/35/documents/ OttawaRiver2007TSD.pdf

[OEPA] Ohio Environmental Protection Agency. 2008. Biological and water quality study of the East Fork Vermilion River green circle growers project 2007. Columbus: Ohio EPA, Technical Report DSW/EAS 2008-2-5. [accessed 2016 March 19].http://www.epa.ohio.gov/portals/35/documents/ EastForkVermilionRiverTSD2008.pdf

[OEPA] Ohio Environmental Protection Agency. 2009. Biological and water quality study of the Swan Creek watershed, 2006: Lucas and Fulton counties. Columbus: Ohio EPA, Technical Report EAS/2008-12-11. [accessed 2016 March 19]. http://www.epa.ohio.gov/portals/35/documents/ SwanCreekTSD2006.pdf

[OEPA] Ohio Environmental Protection Agency. 2010a. Biological and water quality survey of the Portage River Basin, select Maumee River tributaries, and select Lake Erie tributaries, 2006-2008: Hancock, Lucas, Ottawa, Sandusky, Seneca, and Wood counties, Ohio. Columbus: Ohio EPA, Report DSW/EAS 2010-4-4. [accessed 2016 March 19]. http://www.epa.ohio.gov/portals/35/documents/ PortageLETribsMaumeeTribs2010.pdf

[OEPA] Ohio Environmental Protection Agency. 2010b. Biological and water quality survey of the Sandusky Bay tributaries, 2009: Erie, Sandusky, and Seneca counties, Ohio. Columbus: Ohio EPA, Report DSW/EAS 2010-4-6. [accessed 2016 March 19]. http://epa.ohio.gov/portals/35/ documents/SanduskyBayTribsTSD2009.pdf

[OEPA] Ohio Environmental Protection Agency. 2011. Biological and water quality study of the Lower Sandusky River watershed, 2009: Sandusky and Seneca counties, Ohio. Columbus: Ohio EPA, Report DSW/EAS 2011-6-9. [accessed 2016 March 19]. http://www.epa.ohio.gov/portals/35/documents/ SanduskyTSD_2011.pdf

[OEPA] Ohio Environmental Protection Agency. 2012a. Biological and water quality study of the Loss Creek-Sandusky River watershed (HUC 041000110302) Crawford county, Ohio, 2011-2012. Columbus: Ohio EPA, Technical Report EAS/2012-8-10. [accessed 2016 March 19]. http://www. epa.ohio.gov/Portals/35/documents/LossCr_GLRI.pdf

[OEPA] Ohio Environmental Protection Agency. 2012b. Biological and water quality study of Armstrong Creek and the Miami-Erie Canal (Veyance Technologies), 2012: Auglaize county, Ohio. Columbus: Ohio EPA, Report EAS/2012-12-16. [accessed 2016 March 19]. http://www. epa.ohio.gov/Portals/35/documents/VeyanceTSD.pdf

[OEPA] Ohio Environmental Protection Agency (OEPA). 2013. Biological and water quality study of the Ottawa River and principal tributaries, 2010: Allen, Auglaize, Hardin, Hancock, and Putnam counties. Columbus: Ohio EPA, Technical Report EAS/2012-12-13. [accessed 2016 March 19]. http://www. epa.ohio.gov/Portals/35/documents/OttawaR_TSD_2010. pdf
Page LM, Espinosa-Pérez H, Findley LT, Gilbert CR, Lea RN, Mandrak NE, Mayden RL, Nelson JS. 2013. Common and scientific names of fishes from the United States, Canada, and Mexico $7^{\text {th }}$ Edition. Bethesda: American Fisheries Society.

Page LM. 1983. Handbook of darters. Neptune City, NJ: TFH Publications.

Ricciardi A. 2001. Facilitative interactions among aquatic invaders: evidence of 'invasional meltdown' in the Great Lakes. Can J Fish Aquatic Sci 58: 2513-2525.

Ricciardi A. 2006. Patterns of invasion in the Laurentian Great Lakes in relation to changes in vector activity. Div and Distribut 12: 425-433. http://dx.doi.org/10.1111/j.13669516.2006.00262.x

Scott WB. 1967. Freshwater fishes of eastern Canada. 2nd Ed. Toronto: University of Toronto Press.

Simon TP. 1993. Assesment of the range of the threatened darter, Ammocrypta pellucida (Putnam), from the Maumee River basin, Indiana. Proc Ind Acad Sci 102 (1):139-145.

Simon TP. 1994. Ontogeny and systematics of darters (Percidae) with discussion of ecological effects on larval morphology [dissertation]. [Chicago]: Univ of Illinois.

Simon TP. 2011. Fishes of Indiana: a field guide. Bloomington: Indiana University Press.

Simon TP, Whitaker, Jr, JO, Castrale J, Minton SA. 2002. Revised checklist of the vertebrates of Indiana. Proc Ind Acad Sci 111:182-214.

Smith PW. 1965. A preliminary annotated list of the lampreys and fishes of Illinois. Urbana: Illinois Nautral History Survey. Biological Notes No. 54.

Taylor WR. 1969. A revision of the catfish genus Noturus Rafinesque, with an analysis of higher groups in the Ictaluridae. US Natl Mus Bull 282. Washington: Smithsonian. http:// dx.doi.org/10.5479/si.03629236.282.1

Tessler NR, Gottgens JF, Kibbey MR. 2012. The first observations of the eastern sand darter, Ammocrypta pellucida (Agassiz), in the Ohio portion of the Maumee River mainstem in sixty-five years. Am Midl Nat 167: 198-204.

Trautman MB. 1935. List of the fishes of Michigan. Ann Arbor: Michigan Dept Conserv, Instit Fish Res.

Trautman MB. 1957. The fishes of Ohio. Columbus: The Ohio State University Press

Trautman MB. 1981. The fishes of Ohio. Columbus: The Ohio State University Press.

Underhill JC. 1986. The fish fauna of the Laurentian Great Lakes, the St. Lawrence lowlands, Newfoundland and Labrador, pp. 105-159. In Hocutt CH, Wiley EO, editors. The zoogeography of North America freshwater fishes. New York: John Wiley and Sons.

Van Meter HD, Trautman MB. 1970. An annotated list of the fishes of Lake Erie and its tributary waters exclusive of the Detroit River. Ohio J Sci 70: 65-78.

Yoder CO, Beaumier RA. 1986. The occurrence and distribution of river redhorse, Moxostoma carinatum and greater redhorse, Moxostoma valenciennesi in the Sandusky River, Ohio. Ohio J. Sci 86:18-21. 